\title{
Nitrogen Management in Maize Under Rainfed Conditions in the Brazilian Semiarid Region
}

\author{
Micaela B. Pereira ${ }^{1}$, José L. dos S. Gomes ${ }^{1}$, Vademir R. Cavalcante ${ }^{2}$, Bruno de S. Oliveira ${ }^{1}$, Jackson T. Lobo ${ }^{1}$, \\ João E. da S. Ribeiro ${ }^{1} \&$ Fabio Mielezrski ${ }^{1}$ \\ ${ }^{1}$ Federal University of Paraíba, Areia, Paraíba, Brazil \\ ${ }^{2}$ State Agricultural Research Company of Paraíba (EMEPA), Alagoinha, Paraíba, Brazil \\ Correspondence: Micaela B. Pereira, Federal University of Paraíba, 12, Rod Pb-079, Areia, Paraíba, Brazil. Tel: \\ 55-839-8123-2683. E-mail: micaelle.bp@gmail.com
}

Received: February 25, 2019

Accepted: March 28, 2019

Online Published: May 31, 2019

doi:10.5539/jas.v11n7p86

URL: https://doi.org/10.5539/jas.v11n7p86

\begin{abstract}
Zea mays L. presents socioeconomic and cultural importance for the Northeast region of Brazil, its yield is directly related to the productive system, to the edaphoclimatic conditions and to the soil management. The aim of this work was to evaluate the development and the yield of maize under different nitrogen doses in rainfed conditions in the Brazilian semiarid. The experimental design was in randomized blocks, with four treatments and five replications, totalizing 20 experimental plots, with 24 plants each. The treatments were: $\mathrm{T} 1\left(0 \mathrm{~kg} \mathrm{ha}^{-1} \mathrm{of}^{\mathrm{s}}\right.$ $\mathrm{N})$; T2 $\left(40 \mathrm{~kg} \mathrm{ha}^{-1}\right.$ of N); T3 (60 kg ha ${ }^{-1}$ of N) and T4 $\left(80 \mathrm{~kg} \mathrm{ha}^{-1}\right.$ of N). Were evaluated: plant height, culm diameter and number of leaves at 30,45,60,75 and 90 days after emergence; leaf temperature, stomatal conductance, transpiration, liquid photosynthesis and intercellular carbon concentration at 65 days after emergence; yield, shoot dry mass and nitrogen content in the soil after harvest. The different nitrogen doses significantly influenced the plant height, culm diameter and the number of leaves in the different evaluation periods, also influencing the nitrogen levels in the soil after the harvest. There was no difference among treatments for the yield, the registered average was $5,205 \mathrm{~kg} \mathrm{ha}^{-1}$. The development of the crop and the nitrogen absorption may have been influenced by the water deficit during the crop cycle. The maize presented better agronomic performance with the dose of $60 \mathrm{~kg} \mathrm{ha}^{-1}$ of nitrogen.
\end{abstract}

Keywords: nitrogen fertilization, growth, water deficit, productivity, gas exchange, Zea mays

\section{Introduction}

Agricultural production systems, in terms of area and socio-economic importance, are prominent throughout the world. The maize (Zea mays L.) presents a great importance among the cultivated species, being part of the human and animal food chain, due to its grain yield and forage production, being one of the most produced inputs in Brazil and in the world (Souza et al., 2012; Custódio et al., 2016; USDA, 2018).

In the fifth survey of the 2018/2019 harvest conducted by the United States Department of Agriculture, the global production of maize was estimated in 1.07 billion tons (USDA, 2018). In the world ranking, Brazil is the third largest producer with 82 million tons estimated for the 2018/2019 harvest. In the 2016/2017 harvest, maize cultivation in Brazil was performed in an area of 16.1 million hectares, with the Northeast region being responsible for $11.72 \%$ of this total area, and the state of Paraíba with participation of 8.4 million hectares (CONAB, 2017).

Maize crop productivity is directly related to the entire production system, involving the genetic potential of the variety, the edaphoclimatic conditions and the management employed. Among the cultural practices, the management of soil fertility is of great importance in order to achieve higher productivity (Santos et al., 2014; Lins et al., 2017).

Among the macronutrients required by the maize crop, nitrogen $(\mathrm{N})$ is absorbed in higher quantity. Besides its effect on productivity, this nutrient has importance in the biochemical processes of the plant, as a constituent of proteins, enzymes, coenzymes, nucleic acids and chlorophyll (Lourente et al., 2007; Santos et al., 2010). However, nitrogen fertilizers are among the inputs that most burden production, needing to be applied in 
sufficient quantities and in an appropriate manner, in order to minimize environmental costs and damages (Kappes et al., 2014).

There are several researches evaluating the effects of nitrogen fertilization in the development and production of maize (Farinelli \& Lemos, 2010; Carmo et al., 2012; Santos et al., 2013), however, there are still few studies that consider the particularities of the rainfed production system.

In the Brazilian semiarid, the use of mineral fertilizers is highly reduced, due to economic and cultural factors; according to Silva and Menezes (2007), this situation occurs due to the high risk of production losses in function of the variability in the rainfall regime, typical of semiarid regions. Therefore, researches on maize that consider the local climatic conditions and production systems are necessary in order to demonstrate to the farmers the importance of the adequate nutritional management in obtaining high yields.

Based on the foregoing, the aim of this work was to analyze the development of maize (Zea mays L.) under different doses of nitrogen, cultivated under rainfed conditions in the Brazilian semiarid.

\section{Materials and Methods}

\subsection{Geographic Location}

The experiment was conducted in the Experimental Station of the State Agricultural Research Company of Paraíba (EMEPA-PB), municipality of Alagoinha, Paraíba state, from May to September 2018. The area is located in the mesoregion of the agreste paraibano, Brazilian semiarid, located in the geographical coordinates $6^{\circ} 57^{\prime} 00^{\prime \prime} \mathrm{S}$ and $35^{\circ} 32^{\prime} 42^{\prime \prime} \mathrm{W}$, at $154 \mathrm{~m}$ of elevation.

\subsection{Climate Characterization}

The climate of the region, according to classification of Köppen, is As' (hot and humid), with autumn-winter rains and yearly rainfall average of $1,100 \mathrm{~mm}$ (IBGE, 2006). The monthly rainfall data referring to the period of conduction of the experiment are expressed in Figure 1; the accumulated in the period was $847.5 \mathrm{~mm}$.

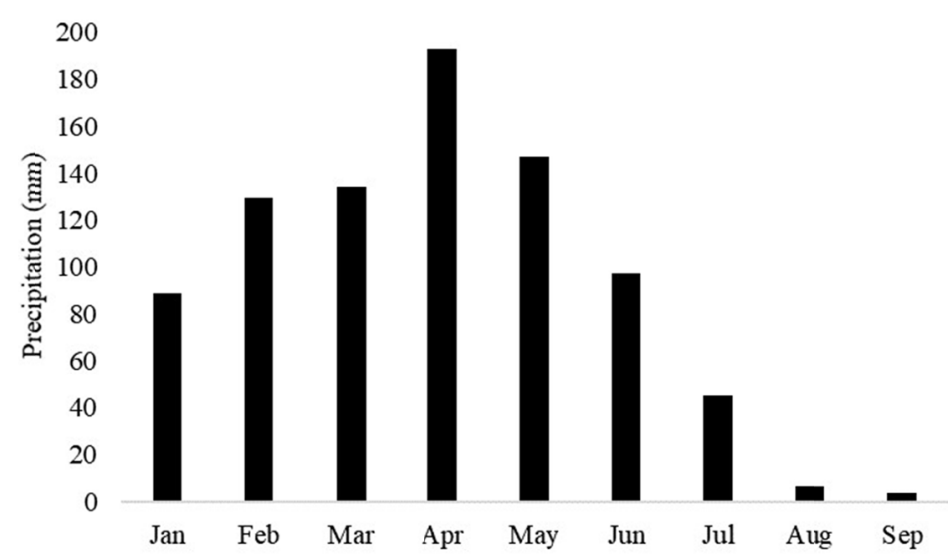

Figure 1. Rainfall data (Jan-Sep/2018), from the EMEPA-PB meteorological station, municipality of Alagoinha-PB, during the experimental period

\subsection{Soil Characterization}

The soil of the experimental area is classified as Haplic Planosol (EMBRAPA, 2009), with the following physical characteristics: 0-0.2 m: sand-548 $\mathrm{g} \mathrm{kg}^{-1}$; silt-247 $\mathrm{g} \mathrm{kg}^{-1}$; clay $205 \mathrm{~g} \mathrm{~kg}^{-1} ; \mathrm{pH}$ in water (1.0:2.5)-5.17; P-2.78 mg dm${ }^{-3} ; \mathrm{K}^{+}-95.87 \mathrm{mg} \mathrm{dm}{ }^{-3} ; \mathrm{Ca}^{2+}-2.85 \mathrm{cmolc} \mathrm{dm} \mathrm{dm}^{-3} ; \mathrm{Mg}^{2+}-0.35$ cmolc dm ${ }^{-3} ; \mathrm{Na}^{+}-0.049 \mathrm{cmolc} \mathrm{dm}^{-3}$; $\mathrm{H}^{+}-\mathrm{Al}^{3+}-5.20 \mathrm{cmolc} \mathrm{dm}^{-3} ; \mathrm{Al}^{3+}-0.40 \mathrm{cmolc} \mathrm{dm}^{-3}$; SB-3.49 $\mathrm{cmolc} \mathrm{dm}^{-3}$; CTCpH7-8.89 $\mathrm{cmolc} \mathrm{dm}^{-3}$.

\subsection{Planting of the Crop}

The maize was sow in May 2018; the Ipanema variety was used, commonly cultivated by farmers in the Brazilian semiarid region. For the cultivation, conventional soil preparation was performed with one plowing an two light harrows, followed by fertilization and sowing.

\subsection{Fertilization}

Fertilization was manually performed, and the doses were calculated based on soil analysis and crop demand, as recommended by Embrapa for the maize crop (Embrapa, 2012). Phosphorus and potassium doses were 
uniformly applied throughout the experimental area, the nitrogen doses were distributed according to the treatments. Were utilized $60 \mathrm{~kg} \mathrm{ha}^{-1}$ of $\mathrm{P}$ and $40 \mathrm{~kg} \mathrm{ha}^{-1}$ of $\mathrm{K}$, the supply sources were single superphosphate $\left(18 \%\right.$ of $\mathrm{P}_{2} \mathrm{O}_{5}, 16 \%$ of $\mathrm{Ca}$ and $\left.8 \% \mathrm{~S}\right)$ and potassium chloride $\left(60 \%\right.$ of $\left.\mathrm{K}_{2} \mathrm{O}\right)$.

\subsection{Experimental Design and Treatments}

The experimental design was in randomized blocks, with four treatments and five replications, totalizing 20 experimental plots. The plots were composed of 4 rows, spaced $0.8 \mathrm{~m}$, and the plants were spaced $0.2 \mathrm{~m}$, totalizing a population of 62,500 plants ha ${ }^{-1}$. The floor area of each plot comprised the two central rows, where 6 randomly selected plants were evaluated, the edges being neglected.

The utilized treatments were: T1 $\left(0 \mathrm{~kg} \mathrm{~N} \mathrm{ha}^{-1}\right)$; T2 $\left(40 \mathrm{~kg} \mathrm{~N} \mathrm{ha}^{-1}\right)$; T3 $\left(60 \mathrm{~kg} \mathrm{~N} \mathrm{ha}^{-1}\right)$ and T4 $\left(80 \mathrm{~kg} \mathrm{~N} \mathrm{ha}^{-1}\right)$. The application of the doses was performed in a divided manner: the first application was performed at 30 days after emergence, and the second at 45 days, the utilized nitrogen source was urea ( $44 \%$ of N).

\subsection{Growth, Gas Exchanges and Nitrogen Analyses}

At 30 days after emergence, six plants were randomly selected from the floor area of each experimental plot, in which were evaluated: plant height (measure of the lap of the plant until its highest leaf, with the aid of a tape measure, graduated in $\mathrm{m}$ ); culm diameter (using a digital pachymeter, measured in millimeters) and number of leaves (fully expanded leaves). These evaluations were repeated every 15 days, totalizing five evaluations.

The analyses of gas exchange and photosynthetic efficiency of the maize leaves in the flowering phase (R1), corresponding to 65 days after sowing, were performed with the aid of an Infrared Gas Analyzer (IRGA), (LI-COR $\AA$, model LI-6400XT), with artificial light of 1500 micro mol. In each plot two plants were evaluated; the analyses occurred in the morning (between 9 and $11 \mathrm{am}$ ), the first leaf opposite and below the spike was analyzed. The photosynthetic variables evaluated were: leaf temperature (Tleaf), stomatal conductance (gs), transpiration (E), liquid photosynthesis (A) and, intercellular carbon concentration (Ci).

The harvest was performed when the grains presented $\pm 20 \%$ humidity on the spike. For the determination of the grain yield, the spikes of three plants per plot were manually harvested, the straw was removed and the threshing was performed. Upon reaching 13\% moisture, the grains were weighed in order to determine the mass of grains per plant; the yield in $\mathrm{kg} \mathrm{ha}^{-1}$ was estimated based on the density of plants (plants ha $\mathrm{h}^{-1}$ ).

For the dry mass analyses of the shoot part, the plants collected for determination of grain yield were dried in a forced air circulation oven at $65 \pm 2{ }^{\circ} \mathrm{C}$ until reaching constant weight, and then weighed in analytical balance and expressed in grams.

\subsection{Statistical Analyses}

$\mathrm{N}$ levels in the soil were evaluated after harvesting, the analysis of the material was performed according to the methodology recommended by Embrapa (1997). In each treatment, four simple samples were collected per block and then formed a single composite sample, thus totalizing 20 samples.

The results were submitted to analysis of variance, the means were compared by Tukey's test at $5 \%$ probability and by polynomial regression (Ferreira, 2000; Banzatto \& Kronka, 2006), using the software SAS (Statistical Analysis System) version 9.3 (SAS, 2011).

\section{Results and Discussion}

\subsection{Plant Height}

From the summary of the analyses of variance by the mean square (Table 1), it was verified that for the variable average height of plants, there was significant difference only at 30 days after emergency (DAE); for the remaining evaluated periods, 45, 60, 75 and 90 DAE there was no significant difference among the treatments. 
Table 1. Analysis of variance for the average height of the maize plants in different growth stages, as a function of nitrogen doses (N). EMEPA Experimental Station-Alagoinha-PB, 2018

\begin{tabular}{llllll}
\hline C. Variation & $30 \mathrm{DAE}$ & $45 \mathrm{DAE}$ & $60 \mathrm{DAE}$ & $75 \mathrm{DAE}$ & $90 \mathrm{DAE}$ \\
\hline "F" Value & $6.09^{* *}$ & $0.38^{\mathrm{ns}}$ & $1.75^{\mathrm{ns}}$ & $0.05^{\mathrm{ns}}$ & $0.11^{\mathrm{ns}}$ \\
\hline $\mathrm{T} 1$ & $0.39 \mathrm{~b}$ & 0.80 & 0.80 & 1.2 & 1.15 \\
$\mathrm{~T} 2$ & $0.36 \mathrm{~b}$ & 0.75 & 0.86 & 1.18 & 1.19 \\
$\mathrm{~T} 3$ & $0.42 \mathrm{~b}$ & 0.77 & 1.10 & 1.18 & 1.18 \\
T4 & $0.55 \mathrm{a}$ & 0.86 & 0.88 & 1.17 & 1.21 \\
\hline LSD & 0.1276 & 0.2964 & 0.3744 & 0.3005 & 0.2942 \\
\hline CV $(\%)$ & 15.22 & 19.02 & 8.33 & 6.90 & 12.79 \\
\hline
\end{tabular}

Note. ${ }^{\text {ns }}, * *, *$ respectively not significative, significative to $P<0.01$ and $P<0.05$. DAE: days after emergency. LSD: least significant difference. CV: coefficient of variation. T1 $\left(0 \mathrm{~kg} \mathrm{~N} \mathrm{ha}^{-1}\right)$; T2 (40 kg N ha $\left.{ }^{-1}\right)$; T3 (60 kg N $\left.\mathrm{ha}^{-1}\right)$ and $\mathrm{T} 4\left(80 \mathrm{~kg} \mathrm{~N} \mathrm{ha}^{-1}\right)$. Means followed by different letters in the same column differ statistically from each other, by the Tukey test at $5 \%$ probability.

At 30 DAE the treatment $\mathrm{T} 4\left(80 \mathrm{~kg} \mathrm{ha}^{-1}\right.$ of $\left.\mathrm{N}\right)$ differed statistically from the other treatments for plant height, being the highest value observed; its mean was $0.19 \mathrm{~m}$ higher than the mean of the remaining treatments $(0.36 \mathrm{~m})$ which did not differ among each other (Figure 2).

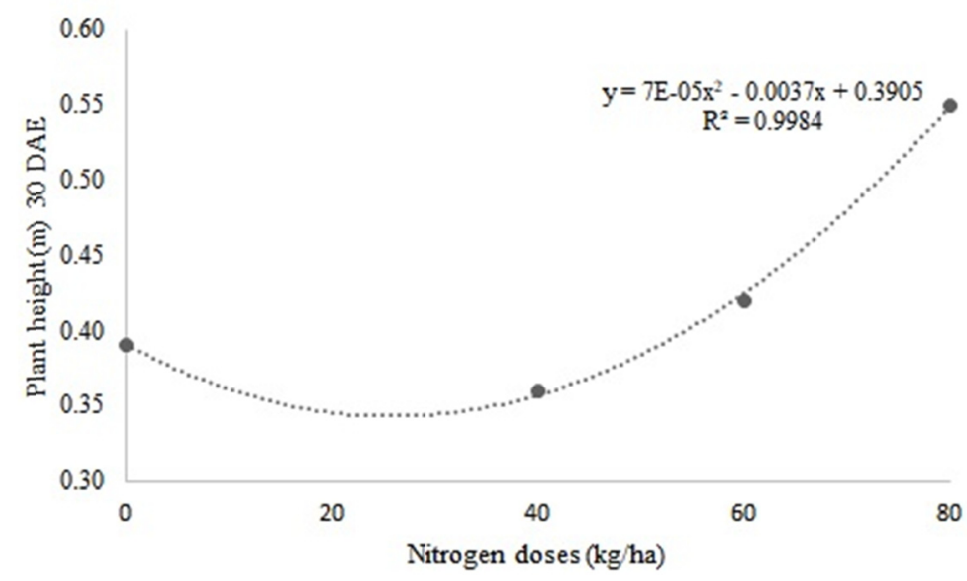

Figure 2. Height of the maize plants, in function of the fertilization with doses of nitrogen $(\mathrm{N})$, at 30 days after emergence

In a study performed at the Cariri region of the state of Ceará, Rolim et al. (2018) also did not obtain significant differences for the variable average height of maize plants, cultivated in rainfed conditions and subjected to nitrogen fertilization in installments. The authors attributed the lack of effect of treatments to the rainfall shortage in the period of crop development, which may have influenced the availability of $\mathrm{N}$, with thus no usage of the nutrient by the plants.

\subsection{Culm Diameter}

For culm diameter, there was effect of the treatments at 30 and 60 DAE (Table 2), however, in the periods of 45, 75 and 90 DAE, no statistical difference was observed for the analyzed variable. 
Table 2. Analysis of variance for maize culm diameter, in different growth stages, as a function of nitrogen doses

(N). EMEPA Experimental Station-Alagoinha-PB, 2018

\begin{tabular}{llllll}
\hline C. Variation & $30 \mathrm{DAE}$ & $45 \mathrm{DAE}$ & $60 \mathrm{DAE}$ & $75 \mathrm{DAE}$ & $90 \mathrm{DAE}$ \\
\hline "F" Value & $5.55^{* *}$ & $2.36^{\mathrm{ns}}$ & $3.49^{* *}$ & $0.90^{\mathrm{ns}}$ & $2.37^{\mathrm{ns}}$ \\
\hline $\mathrm{T} 1$ & $1.22 \mathrm{~b}$ & 1.58 & $1.31 \mathrm{~b}$ & 1.60 & 1.38 \\
$\mathrm{~T} 2$ & $1.08 \mathrm{~b}$ & 1.60 & $1.29 \mathrm{~b}$ & 1.58 & 1.45 \\
$\mathrm{~T} 3$ & $1.25 \mathrm{ab}$ & 1.61 & $1.40 \mathrm{ab}$ & 1.6 & 1.55 \\
$\mathrm{~T} 4$ & $1.57 \mathrm{a}$ & 1.84 & $1.64 \mathrm{a}$ & 1.64 & 1.64 \\
\hline LSD & 0.4279 & 0.3275 & 0.3275 & 0.3035 & 0.2996 \\
\hline CV $(\%)$ & 16.44 & 10.29 & 11.93 & 9.91 & 10.34 \\
\hline
\end{tabular}

Note. ${ }^{\text {ns }}, * *, *$ respectively not significative, significative to $P<0.01$ and $P<0.05$. DAE: days after emergency. LSD: least significant difference. CV: coefficient of variation. T1 $\left(0 \mathrm{~kg} \mathrm{~N} \mathrm{ha}^{-1}\right)$; T2 (40 kg N ha $\left.{ }^{-1}\right) ; \mathrm{T} 3\left(60 \mathrm{~kg} \mathrm{~N}^{\circ}\right.$ $\left.\mathrm{ha}^{-1}\right)$ and $\mathrm{T} 4\left(80 \mathrm{~kg} \mathrm{~N} \mathrm{ha}^{-1}\right)$. Means followed by different letters in the same column differ statistically from each other, by the Tukey test at $5 \%$ probability.

At 30 and 60 DAE the highest values of culm diameter were registered by T4 ( $80 \mathrm{~kg} \mathrm{ha}^{-1}$ of $\left.\mathrm{N}\right)$, with means of 1.57 and $1.64 \mathrm{~cm}$, respectively (Figure 3). At $30 \mathrm{DAE}$, the lowest mean obtained was in $\mathrm{T} 2\left(40 \mathrm{~kg} \mathrm{ha}^{-1} \mathrm{of} \mathrm{N}\right)$, not differing from $\mathrm{T} 1\left(0 \mathrm{~kg} \mathrm{ha}^{-1}\right.$ of $\left.\mathrm{N}\right)$ and $\mathrm{T} 3\left(60 \mathrm{~kg} \mathrm{ha}^{-1}\right.$ of $\left.\mathrm{N}\right)$. In the third evaluation period, corresponding to 60 DAE, the T3 did not statistically differ from the T4 and from other treatments, with a mean of $1.40 \mathrm{~cm}$ in diameter, and the lowest values were for the T2 $\left(40 \mathrm{~kg} \mathrm{ha}^{-1}\right.$ of $\left.\mathrm{N}\right)$ with $1.29 \mathrm{~cm}$.
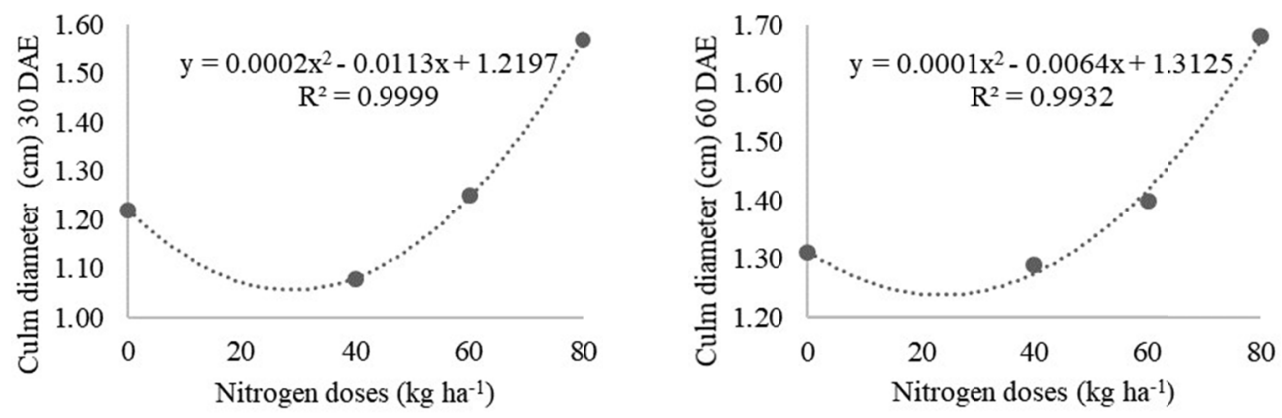

Figure 3. Culm diameter, as a function of the fertilization with doses of nitrogen $(\mathrm{N})$, at 30 and 60 DAE of maize in the field

With the application of 40, 60 and $80 \mathrm{~kg} \mathrm{ha}^{-1}$ of $\mathrm{N}$ applied to the soil through the treatments $\mathrm{T} 2, \mathrm{~T} 3$ and $\mathrm{T} 4$, respectively, there was an increase in the culm diameter in function of the increase of the applied nitrogen doses, in all evaluation periods, when compared to the results obtained in the control treatment. At 30, 45, 60, 75 and 90 DAE there was an increase in $35 \mathrm{~cm}, 26 \mathrm{~cm}, 33 \mathrm{~cm}, 40 \mathrm{~cm}$ and $26 \mathrm{~cm}$, respectively, between the control and the highest dose of $\mathrm{N}$ applied, even though there were no significant differences for the variable culm diameter at 45 , 75 and 90 DAE.

This behavior was similar to that observed by Fernandes et al. (2016) and by Kappes et al. (2014), who verified an increase in culm diameter as a function of the increase of the nitrogen doses applied in the soil.

The increase in the culm diameter with the nitrogen dose is beneficial, since this morphological characteristic is one of the most related with the lodging percentage or plant break in maize. In addition, culm diameter is very important for obtaining a high productivity, sine the larger is the diameter, the higher the plant's ability to store photoassimilates that will contribute to the filling of the grains (Kappes et al., 2011).

\subsection{Number of Leaves}

The number of leaves was influenced by the nitrogen doses at 60 DAE (Table 3), in this period, significant differences may be observed within the applied treatments. At 30, 45, 75 and 90 DAE, there were no significant differences (Table 3). 
Table 3. Analysis of variance for the number of maize leaves in different stages of growth, as a function of nitrogen doses (N). EMEPA Experimental Station - Alagoinha-PB, 2018

\begin{tabular}{llllll}
\hline C. Variation & 30 DAE & 45 DAE & 60 DAE & 75 DAE & 90 DAE \\
\hline "F" Value & $1.63^{\mathrm{ns}}$ & $0.41^{\mathrm{ns}}$ & $2.88^{* *}$ & $1.77^{\mathrm{ns}}$ & $0.92^{\mathrm{ns}}$ \\
\hline $\mathrm{T} 1$ & 7.16 & 8.63 & $8.36 \mathrm{~b}$ & 9.4 & 10.19 \\
$\mathrm{~T} 2$ & 7.16 & 8.73 & $9.09 \mathrm{ab}$ & 10.1 & 10.33 \\
$\mathrm{~T} 3$ & 7.29 & 9.8 & $10.33 \mathrm{a}$ & 10.16 & 10.16 \\
$\mathrm{~T} 4$ & 8.19 & 8.23 & $8.99 \mathrm{ab}$ & 10.3 & 10.76 \\
\hline LSD & 1.5096 & 1.5873 & 1.8203 & 1.1399 & 1.1807 \\
\hline CV $(\%)$ & 10.38 & 8.33 & 10.20 & 5.89 & 5.85 \\
\hline
\end{tabular}

Note. ${ }^{\mathrm{ns}}, * *, *$ respectively not significative, significative to $P<0.01$ and $P<0.05$. DAE: days after emergency. LSD: least significant difference. CV: coefficient of variation. T1 $\left(0 \mathrm{~kg} \mathrm{~N} \mathrm{ha}^{-1}\right) ; \mathrm{T} 2\left(40 \mathrm{~kg} \mathrm{~N}^{-1}\right)$; T3 (60 kg N $\left.\mathrm{ha}^{-1}\right)$ and T4 $\left(80 \mathrm{~kg} \mathrm{~N} \mathrm{ha}^{-1}\right)$. Means followed by different letters in the same column differ statistically from each other, by the Tukey test at $5 \%$ probability.

At 60 DAE the treatment T3 $\left(60 \mathrm{~kg} \mathrm{ha}^{-1}\right.$ of $\left.\mathrm{N}\right)$ stood out with the highest amount of leaves in the plants, with an average of 10.33 leaves, not statistically differing from treatments $\mathrm{T} 2$ and $\mathrm{T} 3$, but differing from $\mathrm{T} 1$, which presented a lower number of leaves, with an average of 8.36 (Figure 4).

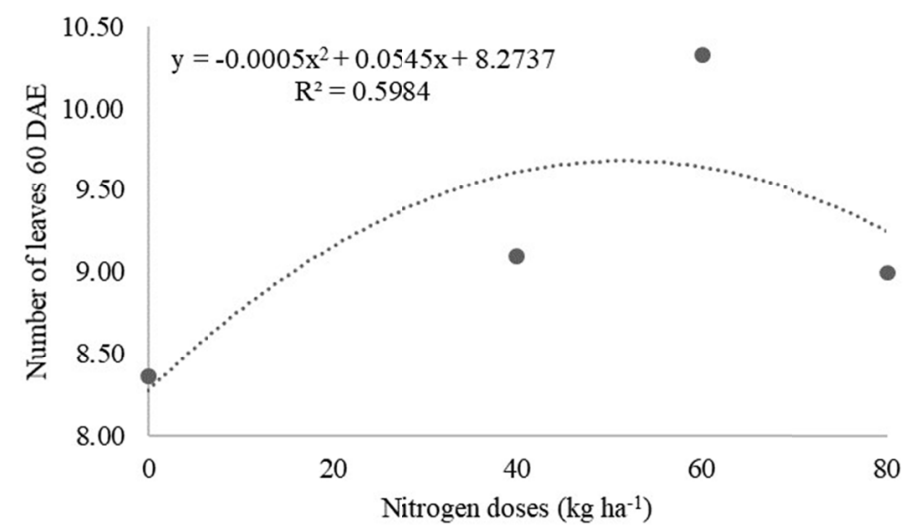

Figure 4. Number of leaves, as a function of the fertilization with nitrogen doses $(\mathrm{N})$, at 60 days after emergence of the maize in field

Significant differences in the development stages, corresponding to 30, 45, 75 and 90 DAE were not found; similar results were reported by Fernandes et al. (2017) in research with maize cultivated as a function of different growing doses of nitrogen, who also did not observe significant differences within treatments.

\subsection{Yield, Dry Mass and Levels of Nitrogen Found in the Soil After Maize Harvest}

For the agronomic variables of yield and dry mass of maize, there were no significant differences among different treatments (Table 4). There was effect of the treatments for the levels of nitrogen in the soil after the harvest (Table 4). 
Table 4. Summary of the analysis of variance for yield $\left(\mathrm{kg} \mathrm{ha}^{-1}\right)$, dry mass and levels of nitrogen found in the soil after maize harvest, as a function of nitrogen doses (N). Experimental Station of EMEPA - Alagoinha-PB, 2018

\begin{tabular}{llll}
\hline C. Variation & Yield & Dry mass & Nitrogen found \\
\hline "F" Value & $2.04^{\mathrm{ns}}$ & $1.99^{\mathrm{ns}}$ & $3.06^{* *}$ \\
\hline T1 & 4.013 .8 & 7.72 & $1.43 \mathrm{a}$ \\
T2 & 3.597 .6 & 7.87 & $1.25 \mathrm{ab}$ \\
T3 & 5.205 .1 & 9.85 & $1.24 \mathrm{ab}$ \\
T4 & 3.779 .8 & 9.12 & $1.16 \mathrm{~b}$ \\
\hline LSD & 2676.4 & 3561.2 & 0.2556 \\
CV $(\%)$ & 35.67 & 22.11 & 10.48 \\
\hline
\end{tabular}

Note. ${ }^{\text {ns }}, * *, *$ respectively not significative, significative to $P<0.01$ and $P<0.05$. LSD: least significant difference. $\mathrm{CV}$ : coefficient of variation. T1 $\left(0 \mathrm{~kg} \mathrm{~N} \mathrm{ha}^{-1}\right)$; T2 $\left(40 \mathrm{~kg} \mathrm{~N} \mathrm{ha}^{-1}\right)$; T3 $\left(60 \mathrm{~kg} \mathrm{~N} \mathrm{ha}^{-1}\right)$ and T4 $(80 \mathrm{~kg} \mathrm{~N}$ $\left.\mathrm{ha}^{-1}\right)$. Means followed by different letters in the same column differ statistically from each other, by the Tukey test at $5 \%$ probability.

In spite of obtaining statistically similar responses, the treatments provided significant variations in the yield results. T3 (60 kg ha ${ }^{-1}$ of $\left.\mathrm{N}\right)$, when compared to the control treatment that did not use nitrogen, promoted an increment of $1,191.3 \mathrm{~kg} \mathrm{ha}^{-1}$. When comparing the average yield of the treatments of the present study, corresponding to $4,149.1 \mathrm{~kg} \mathrm{ha}^{-1}$, with the average yield of the $2017 / 2018$ harvest of the Northeast region, which was $2,554 \mathrm{~kg} \mathrm{ha}^{-1}$ (CONAB, 2018), there is an increase of $62.45 \%$.

It is noteworthy that in the period in which the experiment was developed, the rainfalls for the region of the agreste paraibano were below average, concentrating mainly in the months of February to May, and the beginning of the experiment occurred in May; in the following months, there was a water deficit due to the reduction of rainfall in the region, raining only $297 \mathrm{~mm}$ in the period from May to August, a condition which may have directly influenced the development of the crop due to the lack of water to supply the water requirement of the species, which according to Cruz et al (2010) ranges from 500 to $600 \mathrm{~mm}$, taking into account a regular rainfall distribution, which will depend on the local climatic conditions.

For Paiva et al. (2012) among the main factors responsible for the low productivity of the crop for the semiarid region of Brazil are the irregular rainfall periods and low levels of nitrogen and phosphorus in the soils. There is a lack of research related to nutritional management in field conditions which define adequate doses of nutrients aiming at higher crop yields.

Silva et al. (2014), in work performed in the Apodi Plateau, in the semiarid of Rio Grande do Norte state, evaluated nitrogen and phosphorus doses for maize production in a period in which $332.9 \mathrm{~mm}$ of precipitation were recorded. The effect of the treatments over yield was observed by the authors: with the application of $88 \mathrm{~kg}$ $\mathrm{ha}^{-1}$ of $\mathrm{N}$, a yield of $7,480 \mathrm{~kg} \mathrm{ha}^{-1}$ of maize was obtained. Vilela et al. (2012) when evaluating the effect of $\mathrm{N}$ on grain production, observed that the highest grain yield $\left(5,982 \mathrm{~kg} \mathrm{ha}^{-1}\right)$ was obtained with the dose of $160 \mathrm{~kg}$ ha ${ }^{-1}$, a yield that does not differ with great magnitude from that obtained in this work with the dose of $60 \mathrm{~kg} \mathrm{ha}^{-1}$, which was $5,205.1 \mathrm{~kg} \mathrm{ha}^{-1}$.

For the variable dry mass of the plant, the results obtained by Morais et al. (2018) corroborate with those observed in this study, where the authors also did not observe significant results for shoot dry mass of maize as a function of the application of doses of nitrogen and potassium, where the $\mathrm{N}$ doses of $252 \mathrm{~kg} \mathrm{ha}^{-1}$ and $360 \mathrm{~kg}^{-1}$ were applied.

From the analysis of the $\mathrm{N}$ levels in the soil after the maize harvest, differences among the treatments were

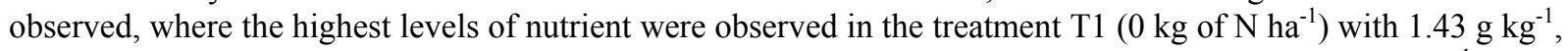
in which no dose of $\mathrm{N}$ was applied. The lowest analyzed levels were in the treatment $\mathrm{T} 4\left(80 \mathrm{~kg} \mathrm{of} \mathrm{N} \mathrm{ha}^{-1}\right)$ with $1.16 \mathrm{~g} \mathrm{~kg}^{-1}$. It is also noted that when compared to the $\mathrm{T} 1$ treatment, a decrease in the levels of $\mathrm{N}$ in the soil also occur for the treatments T2 and T3, what might have occurred because of the larger amount of $\mathrm{N}$ available for the crop, by the addition of the $\mathrm{N}$ doses, thus providing a greater absorption of the nutrient by the plants. 


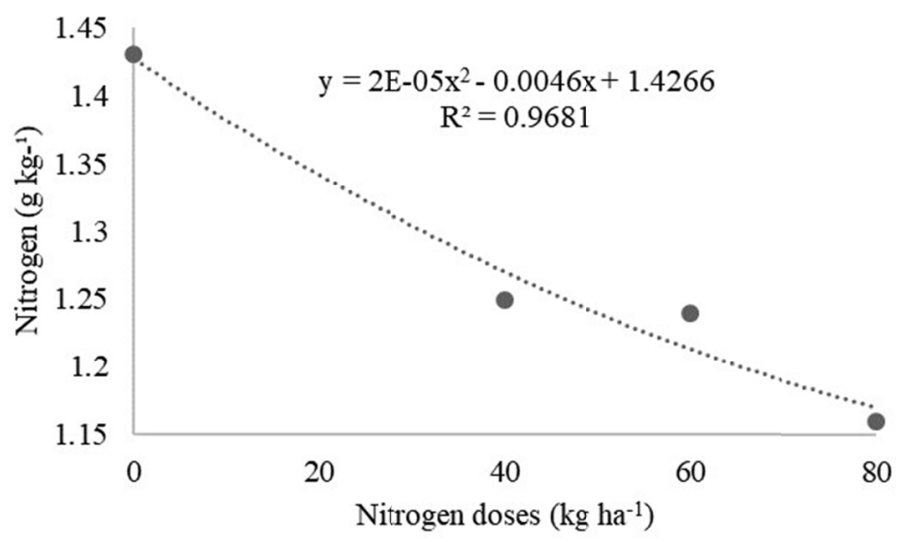

Figure 5. Nitrogen levels in the soil, after harvest, as a function of the fertilization with nitrogen doses in the field

Calonego (2012) highlighted in a performed study that the efficiency in the uptake and translocation of $\mathrm{N}$ by maize is a factor of extreme importance, since it directly influences the final yield of the crop. However, under the conditions of the present experiment, the yield, statistically, was not affected in function of the $\mathrm{N}$ doses, suggesting that the productive response of the crop is a product of the interaction of several factors. However, the obtained yield was higher than the average yield of the region, what could also have been influenced by the fertilization with phosphorus and potassium and not only by the doses of $\mathrm{N}$, since farmers in the semiarid region usually do not use any type of fertilization.

\subsection{Gas Exchange and Liquid Photosynthesis}

In this experiment, it was not observed differences between gas exchange and liquid photosynthesis responses in the plants submitted to the different treatments with nitrogen fertilization (Table 5).

Table 5. Analysis of variance, by the mean square, for leaf temperature $\left(\right.$ Tleaf $\left.-{ }^{\circ} \mathrm{C}\right)$, stomatal conductance (gs-mol $\mathrm{H}_{2} \mathrm{O} \mathrm{m} \mathrm{s}^{-2} \mathrm{~s}^{-1}$ ), transpiration (E-mmol $\mathrm{H}_{2} \mathrm{O} \mathrm{m} \mathrm{s}^{-2}$ ), liquid photosynthesis $\left(\mathrm{A}-\mu \mathrm{mol} \mathrm{CO}_{2} \mathrm{~m}^{-2} \mathrm{~s}^{-1}\right.$ ), internal carbon concentration $\left(\mathrm{Ci}-\mu \mathrm{mol} \mathrm{CO} \mathrm{Col}^{-1}\right.$ ) in maize leaves at the R1 stage, as a function of the nitrogen doses $(\mathrm{N})$. Experimental Station of EMEPA-Alagoinha-PB, 2018

\begin{tabular}{llllll}
\hline C. Variation & Tleaf & gs & E & A & Ci \\
\hline "F" Value & $1.23^{\text {ns }}$ & $0.05^{\text {ns }}$ & $0.09^{\text {ns }}$ & $0.08^{\text {ns }}$ & $0.43^{\text {ns }}$ \\
\hline T1 & 30.869 & 0.206 & 4.481 & 28.291 & 90.316 \\
T2 & 30.754 & 0.219 & 4.641 & 28.326 & 99.324 \\
T3 & 30.377 & 0.210 & 4.393 & 29.390 & 82.012 \\
T4 & 30.432 & 0.213 & 4.389 & 27.920 & 93.480 \\
\hline LSD & 1.0349 & 0.1199 & 1.5648 & 9.2049 & 43.733 \\
\hline CV $(\%)$ & 1.74 & 29.39 & 18.09 & 16.74 & 25.00 \\
\hline
\end{tabular}

Note. ${ }^{\text {ns }}, * *, *$ respectively not significative, significative to $P<0.01$ and $P<0.05$. LSD: least significant difference. CV: coefficient of variation. T1 $\left(0 \mathrm{~kg} \mathrm{~N} \mathrm{ha}^{-1}\right)$; T2 $\left(40 \mathrm{~kg} \mathrm{~N} \mathrm{ha}^{-1}\right)$; T3 $\left(60 \mathrm{~kg} \mathrm{~N} \mathrm{ha}^{-1}\right)$ and T4 $(80 \mathrm{~kg} \mathrm{~N}$ $\left.h^{-1}\right)$.

As observed in Table 5, the values of stomatal conductance varied between 0.206 and $0.219 \mathrm{~mol} \mathrm{H}_{2} \mathrm{O} \mathrm{m}^{-2} \mathrm{~s}^{-1}$. This pattern of variation of the stomatal conductance may be related, among other factors, to the little variation of the environmental factors, being the influence of leaf temperature considered crucial in this process, and for this variable there was a small variation, between 30.4 and $30.9{ }^{\circ} \mathrm{C}$ in this work. The transpiration ranged between 4.389 and $4.641 \mathrm{mmol} \mathrm{H}_{2} \mathrm{O} \mathrm{m}^{-2} \mathrm{~s}^{-1}$ and the results observed among the treatments showed a similar tendency to the responses of leaf temperature and stomatal opening variables owing, in part, to the interdependence between these evaluations (Lopes et al., 2009).

For liquid photosynthesis the results varied between 27.920 and $29.390 \mu \mathrm{mol} \mathrm{CO}_{2} \mathrm{~m}^{-2} \mathrm{~s}^{-1}$. The little variation of liquid photosynthesis may be related the non-variation of physiological factors, such as variation of respiration (Stirling et al., 1994). There are reports in the literature that, with abiotic stresses, liquid photosynthesis 
undergoes strong alternations (Lopes et al., 2009); therefore, since all plants were submitted to water stress, due to natural conditions of rainfall in the period of development of the experiment, it was not possible to statically verify a significant variation. With regard to the internal carbon concentration, an average of $91.283 \mu \mathrm{mol} \mathrm{CO}_{2}$ $\mathrm{mol}^{-1}$ (Table 4); according to Ometto et al. (2003) the $\mathrm{Ci}$ is considered a physiological variable influenced by environmental factors, such as water availability, light and energy, among others.

It is evident from these results that the best agronomic performance concerning plant height, number of leaves, culm diameter and dry mass was obtained with the treatments where the highest doses of $\mathrm{N}$ were applied, 60 and $80 \mathrm{~kg} \mathrm{ha}^{-1}$. Therefore, the use of $60 \mathrm{~kg} \mathrm{ha}^{-1}$ may be recommended for maize fertilization under the conditions of the present study, since the increase in the dose will promote losses of $\mathrm{N}$ to the environment and will burden the plants. The importance of the appropriate nutritional management of the crop is emphasized, necessary for the good development of the plant, even in adverse conditions such as those of agreste paraibano, with low rainfall.

\section{Conclusion}

Nitrogen fertilization influences the plant height, number of leaves and the culm diameter of maize grown in rainfed conditions in the Agreste Paraibano, with the doses up to $60 \mathrm{~kg} \mathrm{~h}^{-1}$ being the most recommended; there was, however, no influence of the nitrogen doses on productivity over the yield in the conditions in which the work was developed.

\section{References}

Banzatto, D. A., \& Kronka, S. N. (2006). Experimentação agrícola (4th ed., p. 237). Jaboticabal: FUNEP.

Calonego, J. C., Palma, H. N., \& Foloni, J. S. S. (2012). Adubação nitrogenada foliar com sulfato de amônio e ureia na cultura do milho. Journal of Agronomic Sciences, 1(1), 34-44.

Carmo, M. S., Cruz, S. C. S., Souza, E. J., Campos, L. F. C., \& Machado, C. G. (2012). Doses e fontes de nitrogênio no desenvolvimento e produtividade da cultura de milho doce (Zea mays convar. saccharata var. rugosa). Biosciencie Journal, 28(Suppl. 1), 223-231.

CONAB (Companhia Nacional de Abastecimento). (2017). Acompanhamento de safra brasileira. Grãos. Safra 2016/2017 (pp. 1-162). Monitoramento Agrícola, Brasília.

CONAB (Companhia Nacional de Abastecimento). (2017/2018). Acompanhamento de safra brasileira. Grãos. Safra 2017/2018. Monitoramento Agrícola, Brasília.

Custódio, C. J. S., Ferreira, J. O., Santos, J. L. S., Camacho, H. A. M., Albino, J. L. D., \& Rodrigues, L. C. (2016). Fatores que contribuíram para o crescimento da produtividade do milho no Brasil. Revista Univar, 1(15), 174-179.

EMBRAPA (Empresa Brasileira de Pesquisa Agropecuária). (1997). Centro Nacional de Pesquisa de Solos, Manual de Métodos de Análise de Solos (2nd ed., p. 212). Rio de Janeiro, Embrapa.

EMBRAPA (Empresa Brasileira De Pesquisa Agropecuária). (2009). Manual de métodos de análise de solo (3rd ed., p. 212). Rio de Janeiro, Embrapa.

Farinelli, R., \& Lemos, L. B. (2010). Produtividade e eficiência agronômica do milho em função da adubação nitrogenada e manejos do solo. Revista Brasileira de Milho e Sorgo, 9(2), 135-146. https://doi.org/10.18512/ 1980-6477/rbms.v9n2p135-146

Fernandes, J. D., Chaves, L. H. G., Monteiro Filho, A. F., Vasconcellos, A., \& Silva, J. R. P. da. (2017). Crescimento e produtividade de milho sob influência de parcelamento e doses de nitrogênio. Revista Espacios, 38(8), 27.

Ferreira, D. F. (2000). Sistema de análises de variância para dados balanceados (SISVAR 4.1, Pacote Computacional). Lavras: UFLA.

Kappes, C., Andrade, J. A. C., Arf, O., Oliveira, A. C., Arf, M. V., \& Ferreira, J. P. (2011). Desempenho de híbridos de milho em diferentes arranjos espaciais de plantas. Bragantia, 70, 334-343. https://doi.org/ $10.1590 / \mathrm{S} 0006-87052011000200012$

Kappes, C., Arf, O., Dal Bem, E. A. Portugal, J. R., \& Gonzaga, A. R. (2014). Manejo do nitrogênio em cobertura na cultura do milho em sistema plantio direto. Revista Brasileira de Milho e Sorgo, 13(2), 201-217. https://doi.org/10.18512/1980-6477/rbms.v13n2p201-217

Lins, J. A., Ferreira, P. V., Assunção, M. C., Santos, D. F. Dos, Carvalho, A. P. V. De, \& Santos, E. A. dos. (2017). 
Crescimento de genótipos experimentais de milho em função de doses crescentes de nitrogênio. Ciência Agrícola, 15(2), 19-27. https://doi.org/10.28998/rca.v15i2.3640

Lopes, J. P., Machado, E. C., Deuber, R., \& Machado, R. S. (2009). Análise de Crescimento e Trocas Gasosas na Cultura de Milho em Plantio Direto e Convencional. Bragantia, 68(4), 839-848. https://doi.org/10.1590/ S0006-87052009000400003

Lourente, E. R. P., Ontocelli, R., Souza, L. C. F., Gonçalves, M. C., Marchetti, M. E., \& Rodrigues, E. T. (2007). Culturas antecessoras, doses e fontes de nitrogênio nos componentes de produção do milho. Acta Scientiarum Agronomy, 29(1), 55-61. https://doi.org/10.4025/actasciagron.v29i1.66

Morais, M., Amaral, H. F., \& Nunes, M. P. (2018). Desenvolvimento e assimilação de nutrientes da cultura de milho inoculado com Azospirillum brasilense e diferentes doses de nitrogênio e potássio. Rev. Terra \& Cult., 34,160 .

Ometto, J. P. H. B., et al. (2003). Variação temporal do isótopo estável do carbono em material arbóreo em florestas da região Amazônica. Congresso Brasileiro de Ecologia 4, Fortaleza. Anais... Rio Claro: Sociedade de Ecologia do Brasil.

Paiva, M. R. de F. C., Silva, G. F. da, Oliveira, F. H. T. de, Pereira, R. G., \& Queiroga, F. M. (2012). Doses de nitrogênio e de fósforo recomendadas para produção econômica de milho-verde na chapada do Apodi-RN. Rev. Caatinga, 25(4), 1-10.

Rolim, R. R., Pinto, A. A., Camara, F. T. da, Mota, A. M. D., \& Silva, C. S. da. (2018). Produtividade e rentabilidade do milho em função do manejo da adubação na região do Cariri-CE. Revista Cientifica Rural, 20(1).

Santos, L. P. D., Aquino, L. A., Nunes. P. H. M. P., \& Xavier. F. O. (2013). Doses de nitrogênio na cultura do milho para altas produtividades de grãos. Revista Brasileira de Milho e Sorgo, 12(3), 270-279. https://doi.org/ 10.18512/1980-6477/rbms.v12n3p270-279

Santos, M. M., Galvão, J. C. C., Silva, I. R., Miranda, G. V., \& Finger, F. L. (2010). Épocas de aplicação de nitrogênio em cobertura na cultura do milho em plantio direto, e alocação do nitrogênio $(15 \mathrm{~N})$ na planta. Revista Brasileira de Ciência do Solo, 34, 1185-1194. https://doi.org/10.1590/S0100-06832010000400018

Santos, P. R., Costa, K. D. S., Carvalho, I. D. E., Silva, J. P., \& Ferreira, P. V. (2014). Desempenho de genótipos de milho (Zea mays L.) submetidos a dois tipos de adubação. Revista Verde de Agroecologia e Desenvolvimento Sustentável, 9(1), 210-215.

Silva, G. F. da, Oliveira, F. H. T. De, Pereira, R. G., Silva, P. S. L., Diógenes, T. B. A., \& Silva, A. R. da C. (2014). Doses de nitrogênio e fósforo para produção econômica de milho na Chapada do Apodi, RN. Rev. Bras. Eng. Agricola e Ambiental, 18(12). https://doi.org/10.1590/1807-1929/agriambi.v18n12p1247-1254

Silva, T. O., \& Menezes, R. S. C. (2007). Adubação orgânica da batata com esterco e, ou, Crotalaria juncea. II Disponibilidade de N, P e K no solo ao longo do ciclo de cultivo. Rev. Bras. Ci. Solo, 31, 51-61. https://doi.org/10.1590/S0100-06832007000100005

Souza, J. A., Buzetti, S., Tarsitano, M. A. A., \& Valderrama, M. (2012). Lucratividade do milho em razão das fontes, doses e épocas de aplicação de nitrogênio. Revista Ceres, 59(3), 321-329. https://doi.org/10.1590/ S0034-737X2012000300005

Stirling, C. M., Aguilera, C., Baker, N. R., \& Long, S. P. (1994). Changes in the photosynthetic light response curve during leaf development of field grown maize with implications for modelling canopy photosynthesis. Photosynthesis Research, 42, 217-225. https://doi.org/10.1007/BF00018264

USDA (United Stades Department of Agriculture). (2018). Wolrd Algricultural Production.

Vilela, R. G., Arf, O., Gitti, D. C., Kappes, C., Goes, R. J., Dalbem, E. A., \& Portugal, J. R. (2012). Manejo do milheto e doses de nitrogênio na cultura do milho em sistema de plantio direto. Rev. Bras. de Milho e Sorgo, 11, 234-242. https://doi.org/10.18512/1980-6477/rbms.v11n3p234-242

\section{Copyrights}

Copyright for this article is retained by the author(s), with first publication rights granted to the journal.

This is an open-access article distributed under the terms and conditions of the Creative Commons Attribution license (http://creativecommons.org/licenses/by/4.0/). 